\title{
Economic Impact of COVID-19 on the Vulnerable Population of Bangladesh
}

${ }^{1}$ Sakib Mahmud, Undergraduate Student, Department of Economics, Shahjalal University of Science \& Technology, Bangladesh. Email: sakib13@student.sust.edu

${ }^{2}$ Sayed Arafat Zubayer, Undergraduate Student, Department of Economics, Shahjalal University of Science \& Technology, Bangladesh. Email: sayed40@student.sust.edu

${ }^{3}$ Ahmed Eshtiak, Undergraduate Student, Department of Economics, Shahjalal University of Science \& Technology, Bangladesh. Email: ahmed042@student.sust.edu

${ }^{3}$ Ibrahim Ahmed, Undergraduate Student, Department of Economics, Shahjalal University of Science \& Technology, Bangladesh. Email: ibrahim80@ student.sust.edu

${ }^{4}$ Mahmudul Hossain Nasim, Graduate Student, Department of Economics, Shahjalal University of Science \& Technology, Bangladesh. Email: mahmudul@student.sust.edu

(Two Co-Authors, Ahmed Ishtiak \& Ibrahim Ahmed have contributed equally)

\begin{abstract}
This study aims to find out the Economic condition of the vulnerable population of Bangladesh in the COVID-19 situation. This study uses the primary data of 203 respondents who were collected from all around Bangladesh using convenience and purposive sampling. In this study, a comparison of expected income in the COVID-19 situation is made with the pre-COVID-19 situation using Welch two-sample t-test, and the possible impact on Expenditure and Savings was discovered using OLS estimation. Descriptive analysis is also included considering the key economic variable of the respondents. This study finds a significant drop in income due to COVID19 and infers that it will cause both drop-in expenditure and monthly savings, and gives an overall idea of the situation of vulnerable people in the COVID-19 situation. This study can help the stakeholders to understand the situation of the vulnerable population of Bangladesh due to COVID-19.
\end{abstract}

\section{Keywords}

COVID-19; Bangladesh; Income; expenditure; Developing; Vulnerable population

\section{JEL Classification: I;E4;H5;H53;H75}




\subsection{Introduction}

Coronavirus disease (COVID-19) first appeared in the Hubei Province of China in December 2019. From China, it has spread all over the world (Hassanin, 2020). The World Health Organization (WHO) described COVID-19 as a pandemic (Boseley, 2020b) and consecutively declared a global health emergency (Boseley, 2020a). According to WHO (World Health Organization), this virus got 1,773,088 confirmed cases with 111,652 deaths out of all the confirmed cases by $13^{\text {th }}$ April 2020, Bangladesh got 621 confirmed cases with 34 deaths by that date ("Coronavirus disease (COVID-19) Pandemic," 2020). The whole world is suffering from this crisis, there is no chance of escape from this virus unless we invent the vaccine but it is supposed to slow down as in some countries this virus infection has reached the saturation point (Knowles, 2020). This virus is having global economic impacts like- demand and supply shocks, disruption in the value chain and supply chains, an increase in the unemployment rate ("Coronavirus: the economic impact," 2020).

In this crisis, the global economy could lose $\$ 3.7$ billion worth of output. COVID-19 could push half a billion people into poverty, the informal sectors of the developing country will face a major hit (K. Ahmed, 2020). The president of the World Bank David Malpass said that the poorest country will hit the most in this economic crisis, especially those countries which have huge debts. In the developing countries of Asia, COVID-19 is causing a decline in domestic demand, tourism business as well it is disrupting trade and supply linkage (Abiad et al., 2020).

Bangladesh is the largest economy among the least developed countries and by 2024 expected to leave the LDCs ("Leaving the LDCs category: Booming Bangladesh prepares to graduate," 2018). This country has a vast population of 168.1 million with a per-capital income of 1,905.7 US\$("Bangladesh,") as of 2019. According to the Bangladesh Bureau of Statistics (BBS) in 2018 the poverty rate in Bangladesh is $21.8 \%$ and people living below the extreme poverty line are $11.3 \%$ ("Poverty rate comes down at 21.8pc in 2018: BBS," 2019). According to the BBS report in the year 2017-18, the economically active population and the employed population were 62.1 million and 59.5 million respectively ("Bangladesh Statistics 2018," 2018). According to an article by ILO (International Labor Organization) about $87 \%$ of the total labor force was employed in the informal sector in 2010 and these informal professions are - wage laborers, self-employed persons, and unpaid family labors.

Due to the effect of the Corona Virus, almost 20 million workers in the informal sector lost their jobs in Bangladesh. A distinguished fellow at CPD (Centre for Policy Dialogue) Dr. Mustafizur Rahman said that both formal and informal sector out of 60.8 million people working, 14 million people get their monthly salary from employers, 10 million workers are day laborers and the remaining 27 million are self-employed with mainly small businesses; out of them in a current pandemic situation, the day laborers and self-employed are temporarily jobless with zero earning ("'Coronavirus: Nearly 20m people become jobless in Bangladesh'," 2020). Bangladesh is the second-largest exporter of garments, this sector is injured by the Corona Virus crisis due to the order cancellation, and worldwide decreasing demand of the consumers (Z. Ahmed, 2020; "Informal economy in Bangladesh,"). Corona Virus has also jeopardized the agriculture sector, due to the decline of demand in the market, the price of vegetables, fruits, eggs has got down 
("Coronavirus: Prices fall in Dhaka kitchen markets," 2020), the milk producers are selling their milk at a very low price which is causing them to incur great loss(Atik, 2020). Side by side of the effects on all other sectors it has affected the remittance also; in March 2020, the total amount of the remittance was found to be 15 months low ("Remittance hit a 15-month low in March due to coronavirus fallout," 2020).

According to the World Bank, the extreme poverty threshold is $\$ 1.9$ per day, and for the lowermiddle-income country, the poverty threshold is $\$ 3.2$ per day ("Poverty and Shared Prosperity 2018," 2018). In Bangladesh, according to the World Bank, only 15\% of the population earns more than $\$ 5.90$ a day and most of the employment is generates in the informal sector out of which a significant portion depends on daily wage to eat (Saleh, 2020). In the context of the economic turmoil due to COVID-19, this paper will consider the vulnerable people who have a monthly income below $\$ 177$, and maximum income was considered $\$ 176.95$ (15,000 Taka). In this paper, an income comparison of the vulnerable people is made, and the relationship between expenditure and savings is expressed using the Least Squared Regression. Moreover, it will give the descriptive statistics analysis of key economic indicators of the respondents.

\subsection{Research Objective}

This research will try to understand the current economic condition of the vulnerable population of Bangladesh. It will try to compare the monthly Income in the COVID-19 scenario with the preCOVID-19 situation and will try to establish a relation of respondents' monthly savings and expenditure with respondent monthly income.

\subsection{Research Question}

1) What is the condition of the vulnerable population of Bangladesh?

2) Has the monthly income dropped significantly, and will it have any impact on monthly expenditure \& savings due to COVID?

This paper is composed of 6 sections, including section 1 as Introductions, \& remaining are Literature Review, Methodology, Results \& Discussion, Conclusion, and References.

\subsection{Literature Review}

The response during the COVID-19 outbreak in China indicates our experience from the 2003 SARS (Severe Acute Respiratory Syndrom) epidemic outbreak played a significant role (McCloskey \& Heymann, 2020). SARS (Severe Acute Respiratory Syndrom), a type of Coronavirus also caused massive havoc to the economy in 2003 with a global loss of 59 billion USD. With the collapse of the US, the European, and Asian markets; also weakened the trade, and travel all around the world (Baric, 2008).

The COVID-19 have impeded the goal of the United Nations of eradicating poverty by 2030, in the most extreme study by Sumner, Hoy, and Ortiz-Juarez (2020) shows that there might be a 20\% 
drop in consumption/income, increasing the number of people living below the poverty line by 420-580 million. Altig et al. (2020) found using economic uncertainty indicators that in the USA and UK COVID-19 is causing great economic uncertainties and economic fallouts. Ludvigson, Ma, and Ng (2020) used the VAR model in the case of the US to find the estimated loss due to COVID-19 and found that for 12 months from the start of this epidemic in the US (February/March 2020) the multi-period shock would cause about $12 \%$ /month loss of industrial production and inservice sector job loss of about 55\%. Empirical evidence suggests that an epidemic outbreak results to reduce consumer expenditure but not across all categories, and using E-commerce as alternative manufacturers, and retailers can lessen the negative impact of an epidemic outbreak (Jung, Park, Hong, \& Hyun, 2016). Ruiz Estrada and Koutronas (2020) suggested based on the 2019-nCOVGEI-Simulator that for the corresponding region both the likelihood and the magnitude of the epidemics are related to the economic dynamics. An African Perspective of COVID-19 impact on the Economy of Nigeria was conducted by Kanu (2020), this paper says that Economic disruption in Nigeria seems to be loss of jobs, disruption of financial markets and corporate sector, loss of income, and gradual recession.

In the unemployment crisis, a rise in government spending could potentially reduce unemployment and could increase output both in that crisis and in the future (Rendahl, 2016). In the time of recession, 2007-08 workers in small farms who have more external financial dependence are comparatively more vulnerable to job loss than the workers in big farms (Duygan-Bump, Levkov, \& Montoriol-Garriga, 2015). Nigeria, a developing country used public money to stimulate the economy in this pandemic crisis to restrict business failure but some responses were inefficient (P. Ozili, 2020).

The socioeconomic impact of the COVID-19 should be reduced for which a proactive management approach should be followed, health policies should be taken by considering social detriments of health, education, and health literacy among the population needs to be increased, national, and international shifts in investments need to be encouraged, a strong private, and public partnership should be built; A unified world council should be established (Evans, 2020). This situation is instigating many countries to develop their public health sector, fixing the economy with the financial stimulus (P. K. Ozili \& Arun, 2020). Sands, El Turabi, Saynisch, and Dzau (2016) also suggests that an infectious health disease as global health should not be neglected, we need to strengthen our public health capabilities to fight those threats. From the African perspective, Ataguba (2020) suggested the governments increase public health spending to tackle the virus. After reviewing all the relevant works a research gap was found that there is no study of the impact of COVID-19 on the vulnerable population of developing countries of Asia like- Bangladesh.

\subsection{Methodology}

The study uses primary data collected during the COVID-19 lockdown scenario of Bangladesh between $4^{\text {th }}$ April 2020 to $6^{\text {th }}$ June 2020 . Both purposive and convenience sampling have been used in the collection of data, the non-random sampling was used as it was very much tough to collect data in the lockdown scenario. We collected a total of the data of 203 respondents from all around 
the country with monthly income below 15,000 Taka, who we generalized as the vulnerable population in Bangladesh. We used Ordinary Least Squares(OLS) linear regression, bar graph, descriptive statistics, Welch two-sample t-test in the analysis of our sample. In this analysis, we used SPSS version $25 \&$ R-Studio version 1.3.95 for the statistical analysis.

\subsection{Analysis}

First of all, we find out the demographics of our total sample, we used bar graphs, pie charts for that purpose. We also made descriptive statistics analysis of respondent's economic variablesmonthly income, monthly expenditure, monthly savings, people working in each family, total savings, days can be run with that savings, and days living on relief. This descriptive analysis also consisted of some categorical variables- alternative earnings, earnings in the COVID-19 situation, have savings, got relief, health insurance, and mobile banking account. We made a comparison of respondents' income in a pre-COVID-19 situation with income in the COVID-19 situation using Welch two-sample t-test. We used two OLS models to build the relationship between respondent's monthly income with monthly expenditures, \& monthly savings respectively.

\subsection{Results \& Discussion}

\subsection{Demographics}

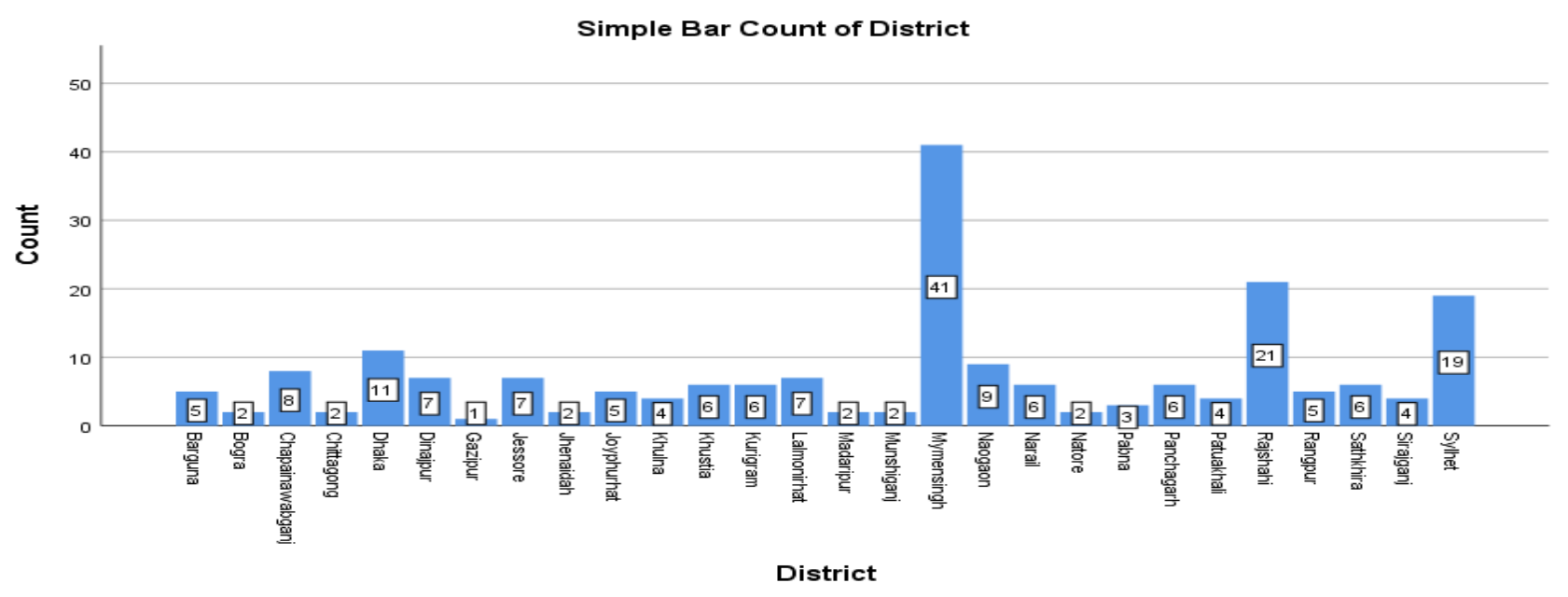

Figure 01 Bar Graph of the District of the Respondents 


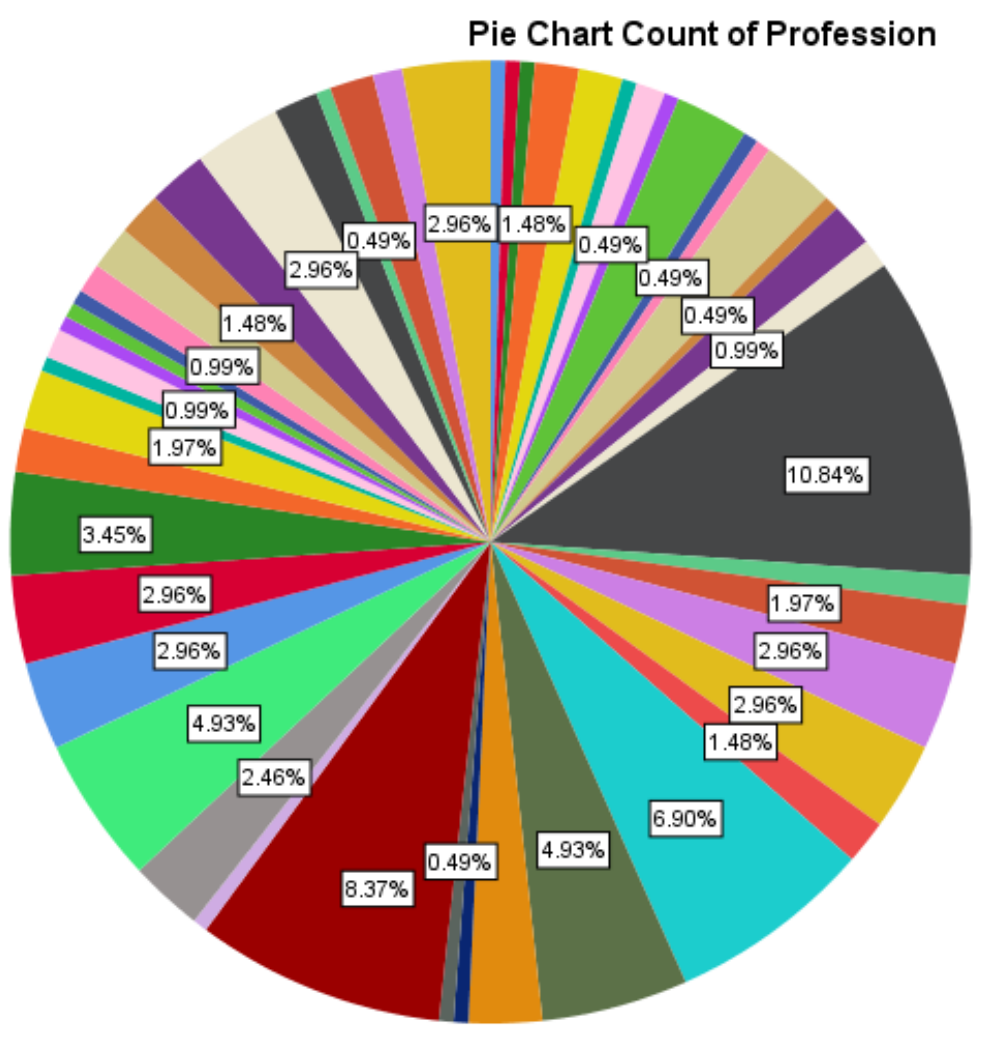

\begin{tabular}{|c|c|}
\hline \multicolumn{2}{|c|}{ Profession } \\
\hline $\begin{array}{l}\text { Auto Rickshaw } \\
\text { Driver }\end{array}$ & $\begin{array}{l}\text { Driver } \\
\text { (Rickshaw) }\end{array}$ \\
\hline Babysitter & Driver (Truck) \\
\hline Bakery Boy & Driver (Van) \\
\hline Barber & - Farmer \\
\hline Bus Conductor & Garments \\
\hline $\begin{array}{l}\text { Care Taker } \\
\text { Carpenter }\end{array}$ & $\begin{array}{l}\text { Worker } \\
\text { - Hawker }\end{array}$ \\
\hline - Cleaner & Hospital Work \\
\hline = Clerk & " Hotel Stuff \\
\hline CNG Driver & Housemaid \\
\hline - Compounder & "House Maid \\
\hline Cook & Mechanic \\
\hline - Craftsman & NGO Worker \\
\hline Day Labour & et Makeı \\
\hline $\begin{array}{l}\text { Day Labour } \\
\text { (Farming) }\end{array}$ & $\begin{array}{l}=\text { Poultry Farmi } \\
\text { "Sales man }\end{array}$ \\
\hline Day Labourer & drity Guaı \\
\hline Day Labourer & \\
\hline $\begin{array}{l}\text { (Farming) } \\
\text { Driver (Auto }\end{array}$ & $\begin{array}{l}\text { Seller (Betel } \\
\text { leaf) }\end{array}$ \\
\hline Rickshaw) & - Seller (Fish) \\
\hline $\begin{array}{l}\text { Driver (Auto- } \\
\text { Rickshaw) }\end{array}$ & Seller (Fruit) \\
\hline Dri & \\
\hline Driver $(\mathrm{Cl}$ & Food) \\
\hline
\end{tabular}

Figure 02 Pie Chart of the Profession of the respondents

Table-1: Gender ratio; Married-Single ratio; Rural-Urban ratio of the respondents

\begin{tabular}{lcccccc}
\hline \multicolumn{2}{c}{ Gender Ratio } & \multicolumn{2}{c}{ Married Single Ratio } & \multicolumn{2}{c}{ Rural-Urban Ratio } \\
\hline Male & Female & Neuter & Married & Single & Urban & Rural \\
\hline $\mathbf{7 5 \%}$ & $23.19 \%$ & $0.99 \%$ & $74.38 \%$ & $25.62 \%$ & $54.68 \%$ & $45.32 \%$ \\
\hline
\end{tabular}

Notably, $75 \%$ of our respondents are male, the remaining $23.19 \%$ and $0.99 \%$ are female and other genders respectively. The majority of the respondents are married which is about $74.38 \%$, and the remaining $25.62 \%$ are single. We tried to collect data from all around Bangladesh about 54.68\% of the respondents are living in the urban area and the remaining $45.32 \%$ of the respondents are from rural areas. The maximum amount of data was collected from Mymensingh (20.2\%), followed by Rajshahi (10.3\%), and Sylhet (9.4\%) and other districts are also notable as shown in Figure 01. Our total sample is composed of respondents with low-paid and vulnerable professions in the context of Bangladesh as shown in Figure 02. 


\subsection{Descriptive Statistics}

Table: 02 Descriptive Statistics of the Continuous Economic Variables

\begin{tabular}{clllll}
\hline Variables & N Statistic & $\begin{array}{l}\text { Standard } \\
\text { Deviation }\end{array}$ & $\begin{array}{l}\text { Minimum } \\
\text { Statistic }\end{array}$ & $\begin{array}{l}\text { Maximum } \\
\text { Statistic }\end{array}$ & $\begin{array}{l}\text { Mean } \\
\text { Statistic }\end{array}$ \\
\hline $\begin{array}{c}\text { Monthly } \\
\text { Income of } \\
\text { the }\end{array}$ & 203 & $2,888.56305$ & 700.00 & $15,000.00$ & $5,748.2759$ \\
respondent & & & & & \\
\hline $\begin{array}{c}\text { Approximate } \\
\text { monthly } \\
\text { expenditure }\end{array}$ & 203 & $2,608.86$ & $2,000.00$ & $15,000.00$ & $6,976.8473$ \\
\hline $\begin{array}{c}\text { Approximate } \\
\text { monthly } \\
\text { savings }\end{array}$ & 203 & 754.354 & -500 & 4,000 & 879.31 \\
\hline $\begin{array}{c}\text { COVID-19 } \\
\text { Monthly } \\
\text { Income }\end{array}$ & 203 & $1,953.275$ & 0 & 10,000 & $1,451.72$ \\
\hline $\begin{array}{c}\text { Total } \\
\text { Savings }\end{array}$ & 203 & $11,409.775$ & 0 & 100,000 & 5131.43 \\
\hline $\begin{array}{c}\text { Days Run } \\
\text { with Savings }\end{array}$ & 156 & 29.346 & 0 & 180 & 36.29 \\
\hline $\begin{array}{c}\text { Days Living } \\
\text { on Relief } \\
\text { Food }\end{array}$ & 145 & 15 & 145 & 90 & 13.78 \\
\hline
\end{tabular}

Table 03 Descriptive Statistics of Categorical Economic Variables

\begin{tabular}{clll}
\hline Variables & $\mathbf{N}$ & Yes & No \\
\hline $\begin{array}{c}\text { Earnings in COVID-19 } \\
\text { Situation }\end{array}$ & 203 & $61.60 \%$ & $38.40 \%$ \\
\hline Have Savings & 203 & $77.30 \%$ & $22.70 \%$ \\
\hline Got Relief & 203 & $70.40 \%$ & $29.60 \%$ \\
\hline Health Insurance & 192 & $6.77 \%$ & $93.23 \%$ \\
\hline Mobile Banking Account & 203 & $62.60 \%$ & $37.40 \%$ \\
\hline
\end{tabular}

As can be seen in Tables $01 \&$ 02; out of the examined 203 respondents' we got the mean of respondent's monthly income, monthly expenditure, and monthly savings of 5,748.28 Taka, 6,976.85 Taka, and 879.31 Taka respectively. It has been found that about $61.60 \%$ out of 203 respondents has earnings in COVID-19 situation and about $77.3 \%$ of the respondent have some sort of savings. The COVID-19 monthly income amount \& total savings amount was of average 1,451.72 Tk. and 5,131.43 Taka respectively. 156 respondents reported that on average they can live about 36 days with savings. Out of 203 respondents', 70.4\% of the respondents said they got food relief, with which 145 respondents said they can run on average 14 days. Out of our 203, respondent's $62 \%$ said they got a mobile banking account, and of about 192 respondents it was found that about $93.23 \%$ said they don't have health insurance. 


\subsection{Variable Relationship Analysis}

Table 04 Welch Two Sample t-test between Monthly Income in Normal Situation and Monthly Income in COVID-19 Situation

\begin{tabular}{cl}
\hline $\begin{array}{c}\text { Mean of } \\
\text { Pre-COVID-19 } \\
\text { Monthly Income }\end{array}$ & $\mathbf{5 , 7 4 8 . 2 7 6}$ \\
\hline $\begin{array}{c}\text { COVID-19 } \\
\text { Monthly Income }\end{array}$ & $1,451.724$ \\
\hline $\begin{array}{c}\text { Confidence } \\
\text { Interval }\end{array}$ & $95 \%$ \\
\hline $\mathbf{t}$ & 17.556 \\
\hline $\mathbf{N}$ & 203 \\
\hline $\mathbf{p}$ & $<2.2 \mathrm{e}-16$ \\
\hline
\end{tabular}

We conducted unequal variance two samples independent welch t-test between Pre-COVID-19 earning \& expected earnings in the COVID-19 situation, the result showed that there was a significant drop in income with a very low p-value at a 95\% confidence interval (Table 03).

\section{Model 01}

Table 05: Ordinary least squares (OLS) regression considering Approximately Monthly Income in Pre-COVID-19 situation as independent Variable and Monthly Expenditure in Pre-COVID-19 Situation as Dependent Variable.

Dependent Variable: Approximately Monthly Expenditure

Method: Least Squares

Included Observations: 203

$\mathbf{R}^{2}=0.497$

Adjusted $\mathbf{R}^{2}=0.494$

\begin{tabular}{cllll}
\hline Variable & Co-efficient & Standard Error & t-Statistic & P-Value \\
\hline Constant & 3318.547 & 290.650 & 11.418 & .000 \\
\hline $\begin{array}{c}\text { Pre-COVID-19 } \\
\text { Monthly }\end{array}$ & .636 & .045 & 14.079 & .000 \\
Income & & & & \\
\hline
\end{tabular}




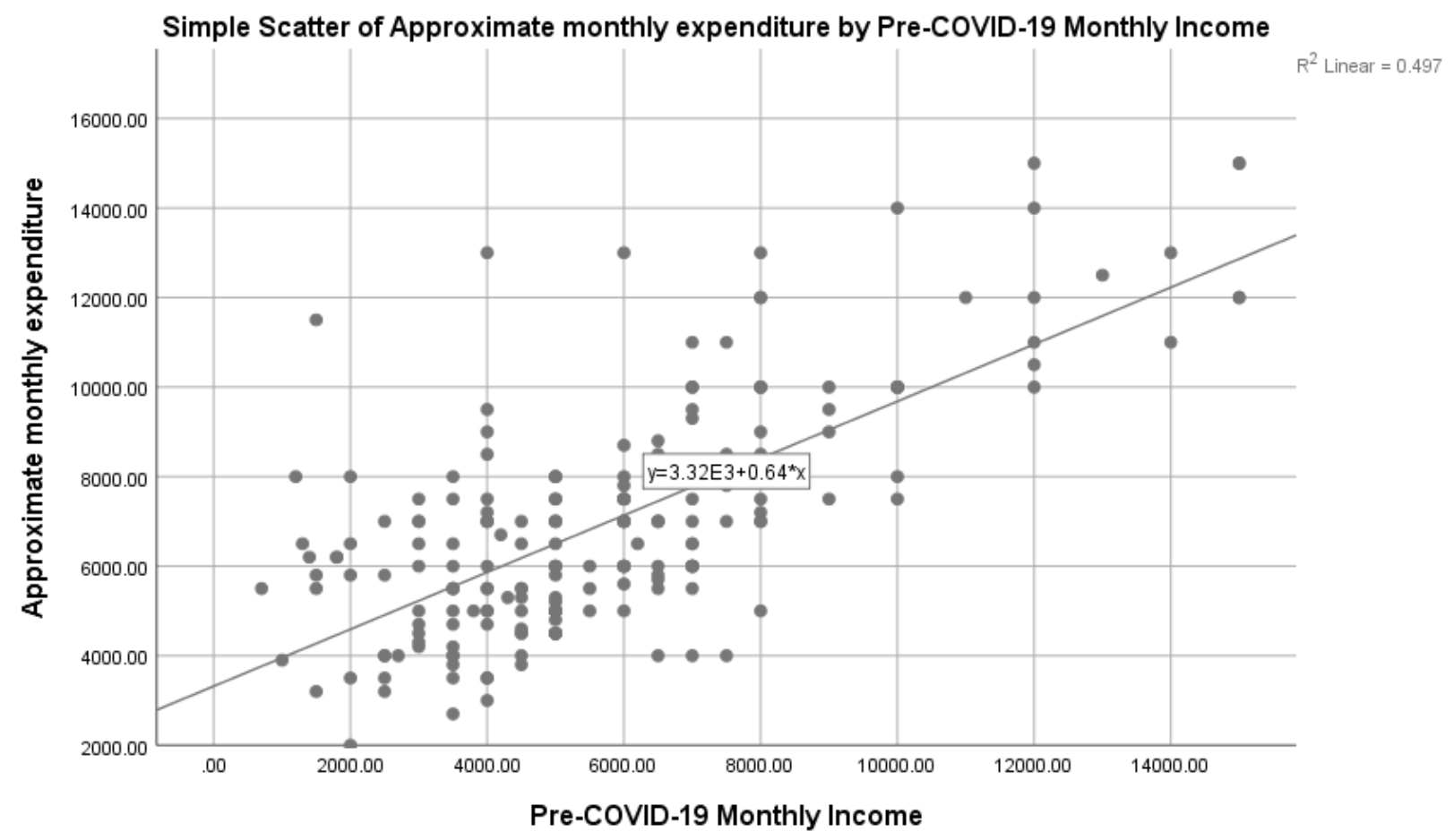

Fig 03 Linear Regression line (OLS) between Monthly Expenditure \& Monthly Income in Normal Situation

This linear model between monthly income \& monthly expenditure in the pre-COVID-19 case showed a significant linear relationship with a very low $\mathrm{p}$-value and the $\mathrm{R}^{2}$ value of this model is also satisfactory, which is about 0.497 which means this model can predict about $49 \%$ of the cases.

The co-efficient of the variable pre-COVID-19 monthly income is 0.636 , which means there is a positive relation between monthly income and monthly expenditure in normal cases. This coefficient can be interpreted as, for every 1 taka increase in monthly income about 0.636 takas in monthly expenditure will be increased, similar impact in case of decreasing income, expenditure will also decrease. 


\section{Model 02}

Table 06: Ordinary least squares (OLS) regression considering Approximate Monthly Income in Pre-COVID-19 situation as independent Variable \& Approximate Monthly Savings in Pre-COVID-19 Situation as Dependent Variable.

Dependent Variable: Monthly Savings

Method: Least Squares

Included Observations: 203

$\mathbf{R}^{2}=0.033$

Adjusted $\mathbf{R}^{2}=0.029$

\begin{tabular}{cllll}
\hline Variable & Co-efficient & Standard Error & t-Statistic & P-Value \\
\hline Constant & 605.299 & 116.453 & 5.198 & .000 \\
\hline $\begin{array}{c}\text { Pre-COVID-19 } \\
\text { Monthly }\end{array}$ & 0.048 & 0.018 & 2.632 & .009 \\
Income & & & & \\
\hline
\end{tabular}

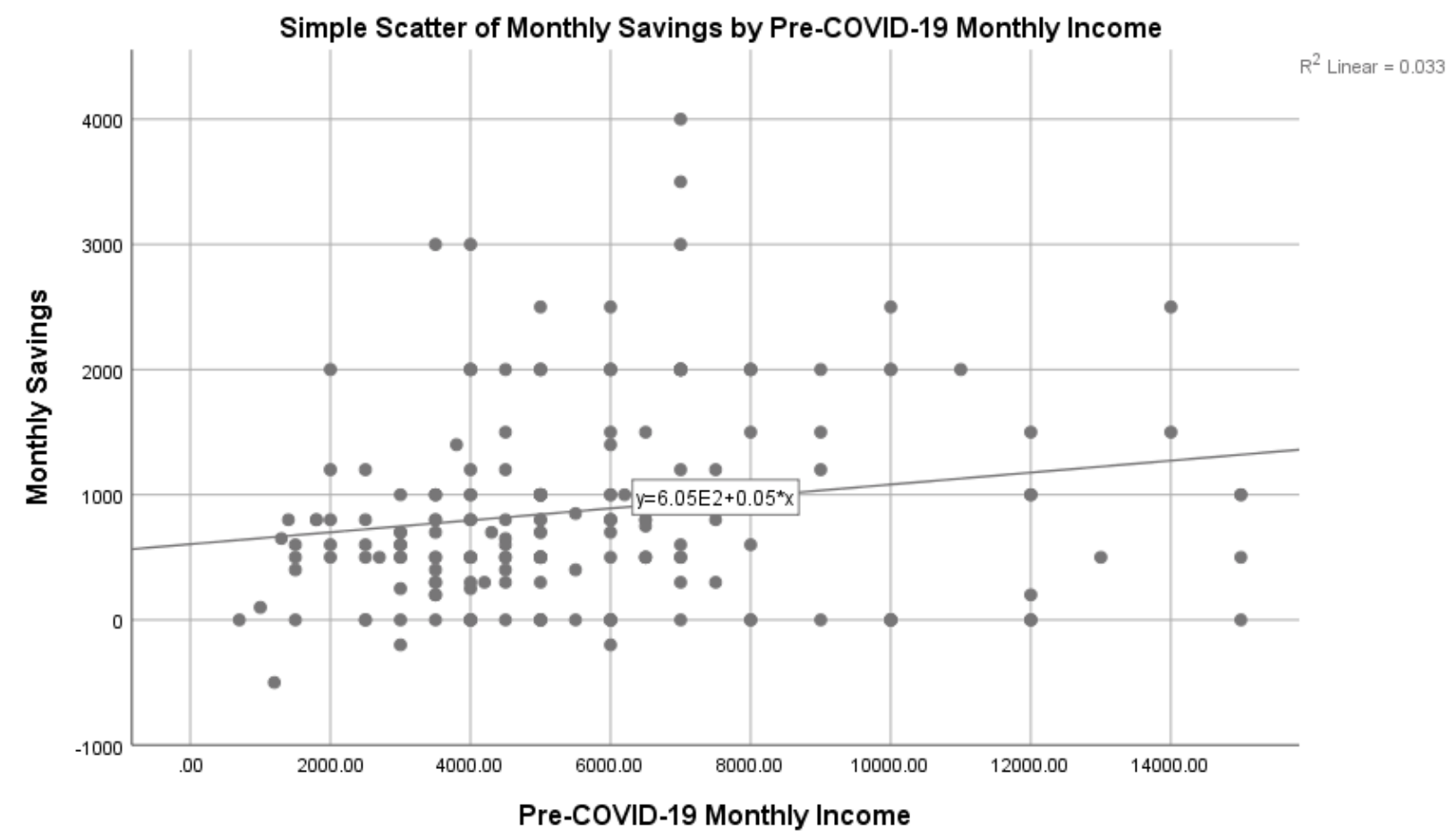

Fig 1.8 Linear Regression line (OLS) between Monthly Income \& Monthly Savings (Pre-COVID-19 Situation)

This linear model between monthly income and monthly savings in pre-COVID-19 condition showed a significant linear relationship with a very low $\mathrm{p}$-value and though the $\mathrm{R}^{2}$ value of this model is not very satisfactory, which is about 0.033 . 
The co-efficient of the variable pre-COVID-19 monthly income is 0.048 , and this relationship with the dependent variable monthly savings is found significant with a p-value of 0.009 at a $95 \%$ interval, which means there is a positive relation between monthly income and monthly savings in a normal case. This co-efficient can be interpreted as, for every 1 taka increase in monthly income about 0.048 takas in monthly savings will be increased. Similar impact in case of decreasing income, savings will also decrease.

As seen in the Welch two-sample t-test the income in COVID-19 has dropped significantly, and the positive and significant relationship of OLS Model 01 and 02 shows that both expenditure and savings will be a drop in the COVID-19 situation, due to fall in the income.

\subsection{Conclusion}

COVID-19 is disrupting the whole global economy, so it is in Bangladesh. As an LDC (Least Developed Country) country the COVID-19 has a much severe impact on the overall economy of Bangladesh. Our research has analyzed different continuous and categorical economic variables of our sampled vulnerable population which can help to overall understand the situation \& more new studies can compare the situation in an updated manner. It has found a significant drop in income due to COVID-19 and signifies that both monthly expenditure and savings will drop, as a significant relation was found between monthly income with both monthly expenditure \& monthly savings separately. Due to the lockdown scenario, a 203 sample was collected using non-random sampling which can't give the proper picture of the vulnerable population. But it can be used to roughly understand the situation.

Conflict of Interest: The authors declared no conflict of interest.

Acknowledgment: The authors would like to thank Professor Dr. Mohammad Abdul Hannan Pradhan, and graduate student of the Department of Economics, Shahjalal University of Science

$\&$ Technology, Susmita Dutta Pritha for their significant guidance \& instructions throughout the journey.

\section{REFERENCES}

Abiad, A., Arao, M., Dagli, S., Ferrarini, B., Noy, I., Osewe, P., . . Platitas, R. (2020). The economic impact of the COVID-19 outbreak on developing Asia.

Ahmed, K. (2020). Coronavirus could turn back the clock 30 years on global poverty, The Guardian. Retrieved from https://www.theguardian.com/global-development/2020/apr/09/coronaviruscould-turn-back-the-clock-30-years-on-global-poverty 
Ahmed, Z. (2020, 25.03.2020). Coronavirus: Bangladesh's garment industry risks collapse, DW. Retrieved from https://www.dw.com/en/coronavirus-bangladeshs-garment-industry-risks-collapse/a52917410

Altig, D., Baker, S., Barrero, J. M., Bloom, N., Bunn, P., Chen, S., . . Mihaylov, E. (2020). Economic uncertainty before and during the covid-19 pandemic. Journal of Public Economics, 104274.

Ataguba, J. E. (2020). COVID-19 pandemic, a war to be won: understanding its economic implications for Africa: Springer.

Atik, R. B. a. F. (2020, 13 Apr 2020). Dairy farmers hit hard by coronavirus lockdown in Bangladesh, bdnews24.com. Retrieved from https://bdnews24.com/bangladesh/2020/04/13/dairy-farmershit-hard-by-coronavirus-lockdown-in-bangladesh

Bangladesh. from https://www.bd.undp.org/content/bangladesh/en/home/countryinfo.html

Bangladesh Statistics 2018. (2018): Bangladesh Bureau of Statistics (BBS), Statistics and Informatics Division (SID) \& Ministry of Planning.

Baric, R. S. (2008). SARS-CoV: lessons for global health. Virus research, 133(1), 1.

Boseley, S. (2020a, 30 Jan 2020). WHO declares coronavirus a global health emergency, The Guardian. Retrieved from https://www.theguardian.com/world/2020/ian/30/who-declares-coronavirus-aglobal-health-emergency

Boseley, S. (2020b, 11 Mar 2020). WHO declares coronavirus pandemic, The Guardian. Retrieved from https://www.theguardian.com/world/2020/mar/11/who-declares-coronavirus-pandemic

Coronavirus disease (COVID-19) Pandemic. (2020). from https://www.who.int/emergencies/diseases/novel-coronavirus-2019

'Coronavirus: Nearly 20m people become jobless in Bangladesh'. (2020, 1 April 2020). Prothom Alo English. Retrieved from https://en.prothomalo.com/business/local/coronavirus-nearly-2mpeople-become-jobless-in-bangladesh

Coronavirus: Prices fall in Dhaka kitchen markets. (2020, 30 March, 2020). The Independent. Retrieved from http://www.theindependentbd.com/post/242976

. Coronavirus: the economic impact. (2020).

Duygan-Bump, B., Levkov, A., \& Montoriol-Garriga, J. (2015). Financing constraints and unemployment: Evidence from the Great Recession. Journal of Monetary Economics, 75, 89-105.

Evans, O. (2020). Socio-economic impacts of novel Corona Virus: The policy solutions. BizEcons Quarterly, 7.

Hassanin, A. (2020, 20 Mar 2020). Coronavirus origins: genome analysis suggests two viruses may have combined. World Economic Forum.

. Informal economy in Bangladesh. International Labour Organization.

Jung, H., Park, M., Hong, K., \& Hyun, E. (2016). The impact of an epidemic outbreak on consumer expenditures: An empirical assessment for MERS Korea. Sustainability, 8(5), 454.

Kanu, I. A. (2020). COVID-19 and the economy: an African perspective. Journal of African Studies and Sustainable Development, 3(2).

Knowles, D. (2020, 06 Apr 2020). How and when will this pandemic end? We asked a virologist. The World Economic Forum.

Leaving the LDCs category: Booming Bangladesh prepares to graduate. (2018, 13 March 2018). Retrieved from https://www.un.org/development/desa/en/news/policy/leaving-the-Idcs-categorybooming-bangladesh-prepares-to-graduate.html

Ludvigson, S. C., Ma, S., \& Ng, S. (2020). Covid19 and the macroeconomic effects of costly disasters: National Bureau of Economic Research.

McCloskey, B., \& Heymann, D. L. (2020). SARS to novel coronavirus-old lessons and new lessons. Epidemiology \& Infection, 148.

Ozili, P. (2020). COVID-19 Pandemic \& Economic Crisis: The Nigerian Experience \& Structural Causes. 
Ozili, P. K., \& Arun, T. (2020). Spillover of COVID-19: impact on the Global Economy. Available at SSRN 3562570.

. Poverty and Shared Prosperity 2018. (2018): The World Bank.

Poverty rate comes down at 21.8pc in 2018: BBS. (2019, May 13, 2019). The Daily Star. Retrieved from https://www.thedailystar.net/country/news/poverty-rate-comes-down-218pc-2018-bbs1742953

Remittance hit a 15-month low in March due to coronavirus fallout. (2020, April 03, 2020). The Daily Star. Retrieved from https://www.thedailystar.net/business/news/remittance-hit-15-monthlow-march-due-coronavirus-fallout-1889209

Rendahl, P. (2016). Fiscal policy in an unemployment crisis. The Review of Economic Studies, 83(3), 11891224.

Ruiz Estrada, M. A., \& Koutronas, E. (2020). The Application of the 2019-nCoV Global Economic Impact Simulator (the 2019-nCoV-GEI-Simulator) in China. Available at SSRN 3542817.

Saleh, A. (2020). In Bangladesh, COVID-19 threatens to cause a humanitarian crisis. World Economic Forum.

Sands, P., El Turabi, A., Saynisch, P. A., \& Dzau, V. J. (2016). Assessment of economic vulnerability to infectious disease crises. The Lancet, 388(10058), 2443-2448.

Sumner, A., Hoy, C., \& Ortiz-Juarez, E. (2020). Estimates of the Impact of COVID-19 on Global Poverty. UNU-WIDER, April, 800-809. 